\title{
Persepsi Partisipan Terhadap Kualitas Pameran Seni Rupa Secara Virtual dalam Situasi Pandemi Covid-19
}

\author{
Fariz Al Hazmi ${ }^{1}$, Kharisma Nanda Zenmira ${ }^{2}$, \\ ST. Agung Budyawan ${ }^{3}$ \\ ${ }^{1,2,3}$ Institut Seni Indonesia Yogyakarta, \\ Jalan Parangtritis KM.6, RW.5, Bantul, Daerah Istimewa Yogyakarta-55188 \\ E-mail: ${ }^{1}$ farizalhazmi16@gmail.com; ${ }^{2}$ knandazenmira@gmail.com; \\ 3agnbudyawan@gmail.com
}

\begin{abstract}
ABSTRAK
Pandemi Corona Virus Disease (Covid-19) yang terjadi belakangan ini menyebabkan perubahan dalam beberapa tatanan kehidupan masyarakat dan bentuk kegiatan publik, salah satunya adalah pameran seni rupa. Peralihan konsep dan cara pameran yang sebelumnya dilakukan secara tatap muka kemudian menjadi virtual/daring tentunya hal ini dapat memengaruhi kualitas sebuah pameran, baik dari segi pelayanannya, konsep display maupun sistem informasi yang digunakan, sehingga pemangku kepentingan dalam pameran memiliki peran dan tanggung jawab untuk membuat suatu pameran tersebut tetap berkualitas dan memberikan pengalaman serta kepuasan kepada pengguna jasa meskipun pameran tersebut berbasis virtual. Pengujian kualitas pameran dilakukan dengan melakukan wawancara semi terstruktur kepada tujuh orang narasumber pengguna jasa pameran virtual/daring dan diukur melalui lima dimensi kualitas pelayanan, yaitu Tangible, Reliability, Responsiveness, Empathy, dan Assurance. Berdasarkan hasil penelitian yang dilakukan, pameran secara virtual/daring memberikan pengalaman yang baru bagi para pengguna jasa yang belum pernah mereka rasakan sebelumnya. Meskipun mengalami situasi perubahan dari pameran secara tatap muka ke pameran secara virtual/daring, kualitas pameran masih sangat baik karena pemangku kepentingan memperhatikan tiap karya yang dipamerkan dari partisipan sebagai pengguna jasa. Hal tersebut menunjukkan bahwa dimensi tangible (bukti fisik), reliabilitiy (keandalan), responsiveness (cepat tanggap), dan empati dalam pameran virtual memiliki kualitas yang baik dan secara positif memberikan dampak kepuasan terhadap pengguna jasa. Sedangkan pada dimensi assurance (jaminan), pemangku kepentingan tidak memengaruhi kepuasan terhadap pengguna jasa, karena kualitas assurance (jaminan) berasal dari kesadaran pengguna jasa dalam berkarya yang harus tetap mengikuti pameran walaupun dengan situasi yang berbeda.
\end{abstract}

Kata kunci: pameran virtual, pemangku kepentingan, pengguna jasa, kualitas layanan

\section{Participants' Perceptions of the Virtual Agency of Art Exhibition Quality in the Covid-19 Pandemic Situation ABSTRACT}

The Corona Virus Disease Pandemic (Covid-19) that has occurred recently has caused changes in various structures of community life and forms of community activities, one of which is an art exhibition. The transfer of the concept and mode of the exhibition that was previously carried out face-to-face to virtual/daring, of course, can affect the quality of an exhibition, both in terms of service, display concept and information system used, so that stakeholders in the exhibition have roles and responsibilities. responsible for realizing exhibitions that remain of high quality and provide experience and satisfaction to service users even though the exhibition is virtually based. Exhibition quality testing is carried out by conducting semi-structured interviews with seven 
speakers using virtual/daring exhibition services and measured through five dimensions of service quality, namely Tangible, Reliability, Responsiveness, Empathy, and Assurance. Based on the results of the research conducted, virtual/daring exhibitions provide new experiences for service users that they have never experienced before. Although the situation has changed from face-to-face exhibition to virtual/daring exhibition, the quality of the exhibition is still very good because stakeholders pay attention to every work on display from participants as service users. This shows that the dimensions of tangible, reliability, responsiveness, and empathy in virtual exhibitions have good quality and have a positive effect on service user satisfaction. Whereas in the dimension of assurance, stakeholders do not affect service user satisfaction, because quality assurance comes from the awareness of service users in their work who must continue to participate in exhibitions even in different situations.

Keywords: virtual exhibition, stakeholders, service users, service quality

\section{PENDAHULUAN}

Pandemi Covid-19, selama tahun 2020 ini telah mengubah kebudayaan di seluruh dunia. Orang dituntut untuk melaksanakan protokol kesehatan dan membatasi kerumunan atau physical distancing untuk mencegah penularan virus corona. Kondisi tersebut mengharuskan para pembuat kebijakan untuk mampu bersikap responsif dan adaptif, baik terhadap bentuk dan jenis kebutuhan publik yang telah mengalami perubahan akibat suatu kondisi sosial tertentu maupun responsif dan adaptif terhadap perubahan publik akibat perkembangan teknologi yang sedang terjadi (Anderson, 1979). Akibat dari pandemi Covid-19 tersebut, banyak event dan festival seni kemudian beralih format ke dalam bentuk virtual yang berbasis internet dan aplikasi teknologi informasi, tidak terkecuali kegiatan pameran yang harus mengubah strategi untuk tetap berjalan tanpa harus menciptakan kerumunan. Penutupan paksa fungsi bisnis dan perpindahan ke operasi jarak jauh menciptakan tantangan tambahan bagi kepemimpinan, sehingga seorang pemimpin harus siap untuk bereaksi dengan cepat dan efisien dalam menanggapi rekomendasi dari pemerintah dan organisasi kesehatan, serta proaktif dalam mengenali dan memahami epidemi/pandemi, gejalanya, efek fisik, dan emosional pada personal (Biddle, 2020). Kepemimpinan dalam hal ini merupakan bagian dari pemangku kepentingan sebagai penyelenggara pameran.

Kemajuan teknologi yang semakin berkembang, serta keadaan yang mengharuskan untuk beralih kepada suatu bentuk adaptasi baru, hal ini memaksa sebuah pameran seni beralih ke dalam bentuk pameran virtual atau daring. Pemangku kepentingan sebagai penyelenggara mendapatkan tanggung jawab yang besar untuk dapat membuat pameran berjalan dengan baik, serta dapat menarik minat para pengguna jasa sebagai partisipan yang belum terbiasa dalam sistem pameran virtual/daring tersebut, di mana sebelumnya, pameran biasa dilakukan secara langsung. Interaktivitas daring telah memperluas cara individu mengalami 
koneksi, keintiman, dan sentuhan (Bennett, 2020), dan segala kelebihan teknologi telah membawa manusia untuk tetap berinteraksi (Salim, 2018).

Menurut Khairunnisa dkk., (2021), pameran virtual merupakan kumpulan replika digital dari peristiwa atau objek nyata yang dikembangkan dengan bantuan alat multimedia dan virtual reality yang menghasilkan sebuah lingkungan simulasi di komputer dan disampaikan melalui web. Sehingga dalam hal tersebut, bidang seni rupa mengikuti perkembangan teknologi informasi, di mana pemangku kepentingan dan partisipan dapat memiliki ruang di halaman web, memajang karya seni, dan memberikan informasi yang lengkap mengenai karya seni yang dibuat secara daring (Maulina, 2019). Dari peralihan pameran secara langsung ke pameran secara virtual tentu memengaruhi kualitas dari pameran tersebut, terutama pada kualitas layanan yang diberikan oleh pemangku kepentingan sebagai penyelenggara dan dapat memberikan pengalaman yang baru bagi pengguna jasa sebagai partisipan yang merasakannya. Pameran virtual menjadi sebuah solusi di tengah larangan berkerumun saat situasi pandemi Covid-19 dan pembatasan sosial berskala besar (Budiyanto dkk, 2020).

Mengingat bahwa pameran virtual memberikan suasana yang berbeda dengan pameran secara tatap muka dapat menimbulkan suatu dampak terhadap kualitas layanan, terutama jika menimbulkan dampak yang kurang memuaskan bagi partisipan akan menurunkan minat untuk kembali mengikuti pameran tersebut. Menurut Anggiansyah (2018), dampak dari kualitas layanan suatu pameran yang dianggap kurang memuaskan bagi partisipan, dapat membuat mereka memilih pameran di galeri lain atau melakukan pameran secara tunggal atau bersama komunitas. Kualitas layanan diartikan sebagai kualitas kesan pelanggan pada superioritas/inferioritas yang relatif terhadap penyedia layanan dan layanannya, dan sering dianggap serupa dengan sikap keseluruhan pelanggan terhadap perusahaan (Parasuraman dkk., 1988). Dalam hal tersebut kualitas pameran virtual dapat diukur dari sudut pandang pengalaman partisipan sebagai pengguna jasa terhadap pelayanan pemangku kepentingan sebagai penyelenggaranya untuk menemukan bagaimana kualitas pameran pada masa pandemi Covid-19.

Jenis pengukuran kualitas melalui pengguna jasa atau partisipan merupakan perspektif eksternal, yaitu memahami kualitas berdasarkan persepsi, sikap kepuasan, ekspektasi, dan customer delight (Sachdev \& Verma, 2004; dalam Tjiptono \& Chandra, 2016). Kualitas sangat berkaitan erat dengan kepuasan pelanggan atau pengguna jasa dan memberikan dorongan khusus untuk menjalin ikatan relasi saling menguntungkan dalam jangka panjang (Tjiptono \& Chandra, 2016). 


\section{TINJAUAN PUSTAKA}

Bonis dkk. (2013), menjelaskan bahwa pameran daring atau virtual adalah representasi 3D realistik tunggal atau multipengguna, di mana pengunjung menavigasi, mengamati pameran, mempelajari informasi terkait tentangnya yang disajikan di berbagai media, dan dalam beberapa kasus pameran virtual tidak memiliki batasan fisik, di mana pemangku kepentingan dapat menyelenggarakan pameran dalam jumlah yang tidak terbatas dalam ruang presentasi yang sangat besar. Hasil menyebutkan bahwa dalam kasus pameran virtual yang dilakukan oleh museum tradisional dapat meningkatkan kunjungan karena memberikan kemampuan adaptasi dan perluasan presentasi karya museum tersebut.

Pameran daring merupakan acara yang dapat dinikmati melalui komputer atau telepon genggam di mana saja dan kapan saja, dengan membutuhkan internet. Meskipun kata daring dan virtual terdengar sama, namun kenyataannya pameran daring dan virtual memiliki perbedaan yang tipis, karena semua pameran virtual adalah daring, tetapi tidak semua pameran daring adalah virtual dan biasanya semua pameran virtual akan menyediakan simulasi lingkungan nyata yang sedikit lebih sulit serta memakan waktu untuk mengembangkannya daripada pameran daring yang sederhana (Ramaiah, 2014). Namun, pameran virtual memangkas biaya produksi dan penyelenggara tidak perlu menyiapkan anggaran khusus untuk mengirimkan karya, akomodasi seniman, sewa ruang pameran, publikasi, dan teknis lainnya (Carollina, 2020).

Karya seni mengalami beberapa perubahan saat berada di lingkungan kerja barunya, di mana penampil dan pengamat tidak melihat karya secara langsung, melainkan melalui layar dan monitor sehingga mereka menemukan dunia baru yang sepenuhnya virtual (Iordache, 2010). Xiaodan (2020) melakukan penelitian terhadap pameran virtual di China sebagai respons Covid-19, menyatakan bahwa bentuk inisiatif partisipatif daring telah memberikan kontribusi besar terhadap sirkulasi informasi dan dukungan dalam berbagai aspek untuk mengatasi pandemi. Menurut Khoon (2008) dalam penelitiannya menjelaskan bahwa pameran daring menghadirkan solusi praktis dan hemat biaya untuk keterbatasan pameran fisik, serta mereka tidak lagi dibatasi waktu, jarak, dan ruang. Peralihan ke ruang daring baru-baru ini telah membawa karya-karya tersebut ke permukaan sebagai bentuk bagaimana terus berkreasi melalui media digital, akan tetapi pergeseran tersebut membutuhkan definisi ulang dari konsep budaya tentang kehidupan dan arti pertemuan satu sama lain, sehingga dengan mendefinisikan hal tersebut ruang pertemuan virtual memiliki potensi untuk memperluas cara kita mengalami keintiman, koneksi, dan sentuhan virtual (Bennett, 2020).

Dunia maya tidak hanya berfungsi sebagai tempat penciptaan tetapi juga sebagai arena pameran, di mana pengunjung dapat berspekulasi tentang ide melalui 
pengalaman interaktif dan multimodal mereka dengan karya seni atau ruang virtual dan merumuskan konsep yang dipelajari sebagai konstruksi pengetahuan baru individu mereka (Lu \& Jeng, 2006; dalam Lu, 2013). Schubert (2008), mengatakan bahwa pameran virtual memberikan perluasan jangkauan daripada pameran secara fisik, mengembangkan kemampuan untuk terlibat dalam berbagai bentuk media (teks, gambar, audio, suara, video, komponen augmented reality dan realitas virtual) dalam satu sistem, dapat mengunjungi kembali, menerjemahkan, dan membaca teks yang disesuaikan untuk kelompok pengguna yang berbeda.

Kunci keberhasilan setiap acara virtual adalah jumlah pengunjung, semakin besar jangkauan pengunjung maka pengguna jasa semakin senang. Oleh karena itu, setiap organisasi yang menerapkan acara virtual disarankan untuk mengembangkan rencana pemasaran yang akan menghasilkan peluang bisnis untuk pengguna jasa yang berpartisipasi (Edgar, 2002). Pameran seni juga perlu memperhatikan pengelolaannya yang harus dilakukan secara terorganisasi, sehingga akan membuat partisipan pameran menjadi lebih fokus dan memperoleh suasana kerja yang kondusif dalam menciptakan karya-karya mereka untuk dipamerkan (Rahmawati, 2015).

Wu dkk. (2016), menjelaskan bahwa hubungan positif yang teridentifikasi antara kualitas layanan pameran dan emosi pengguna jasa dapat diartikan semakin tinggi kualitas layanan pameran yang dirasakan oleh pengguna jasa sebagai partisipan dan bagian terpenting dalam menemukan sebuah kualitas layanan pameran secara virtual antara lain perilaku petugas dari kualitas interaksi, bentuk fisik dari kualitas fisik, kemampuan sosialisasi dari kualitas akses, dan pendaftaran dari kualitas hasil. Seorang pemimpin harus memahami pentingnya tetap terhubung dan bersikap proaktif dalam mengubah pengaturan fisiknya (Biddle, 2020).

Parasuraman, Zeithaml, \& Berry (1988) mengatakan bahwa kualitas pelayanan dapat diartikan sebagai keseluruhan penilaian atau sikap yang berhubungan terhadap keunggulan layanan dari pengguna layanan terhadap penyelenggaraan layanan yang terbagi ke dalam lima dimensi/bagian, yaitu:

1. Tangible (bentuk fisik) yaitu berupa penampilan fasilitas fisik, peralatan, pegawai, dan material yang dipasang. Dimensi ini menggambarkan wujud secara fisik dan layanan yang akan diterima oleh konsumen.

2. Reliability (keandalan) yaitu kemampuan untuk memberikan jasa yang dijanjikan dengan handal dan akurat. Dalam arti luas, kendala berarti bahwa perusahaan memberikan janji-janjinya tentang penyediaan (produk atau jasa yang ditawarkan), penyelesaian masalah, dan harga yang diberikan.

3. Responsiveness (cepat tanggap) yaitu kesadaran dan keinginan untuk membantu pelanggan dan memberikan jasa dengan cepat. Dimensi ini 
menekankan pada perhatian dan ketepatan ketika berurusan dengan permintaan, pertanyaan, dan keluhan pelanggan.

4. Empathy (empati) yaitu kepedulian dan perhatian secara pribadi yang diberikan kepada pelanggan. Inti dari dimensi ini adalah menunjukkan kepada pelanggan melalui layanan yang diberikan bahwa pelanggan itu spesial dan kebutuhan mereka yang dapat dipahami.

5. Assurance (jaminan) yaitu pengetahuan, sopan santun, dan kemampuan karyawan untuk menimbulkan keyakinan dan kepercayaan. Dimensi ini diperlukan agar pelanggan merasa aman dan terjamin.

\section{METODE PENELITIAN}

Penelitian ini menggunakan desain penelitian kualitatif dengan maksud agar peneliti lebih leluasa dalam mengkaji dan menganalisis pengalaman pengguna jasa dalam hubungannya dengan kualitas pelayanan pameran secara virtual pada masa pandemi Covid-19 ini menggunakan sudut pandang dari lima dimensi Parasuraman. Model tersebut yang kemudian berkembang dan sering disebut sebagai "kerangka dasar" dan digunakan secara luas pada berbagai bentuk layanan bisnis dengan berbagai adaptasi.

Penelitian kualitatif ini dalam mengambil data di lapangan dengan menggunakan wawancara semi terstruktur. Brinkmann dan Kvale (2015) mendefinisikan wawancara semi terstruktur sebagai "suatu wawancara yang bertujuan mendapatkan gambaran dunia kehidupan orang yang diwawancarai untuk menafsirkan makna dari fenomena yang digambarkan." Dari pemahaman tersebut, wawancara semi terstruktur memudahkan peneliti untuk mengembangkan pemahaman dalam mengeksplorasi ide dan pengalaman responden.

Wawancara dilakukan kepada tujuh orang narasumber yang pernah mengikuti pameran virtual/daring. Narasumber dipilih dari beberapa kegiatan pameran, yaitu pameran "Identitas" tugas akhir mahasiswa, pameran "Relijiusitas" Kontemporer Nusantara, Pameran Drawing AlkmaArt "Orek-Orek", Pameran Swakarya Kolektif, dan pameran GI_Arscademia. Berikut data pameran dan narasumber: 
Tabel 1. Data Pameran dan Narasumber Partisipan

\begin{tabular}{|c|c|c|c|}
\hline Nama Pameran & $\begin{array}{l}\text { Lokasi \& Waktu } \\
\text { Pameran }\end{array}$ & $\begin{array}{c}\text { Skala } \\
\text { Pameran }\end{array}$ & $\begin{array}{c}\text { Identitas } \\
\text { Narasumber }\end{array}$ \\
\hline $\begin{array}{l}\text { Pameran Seni Rupa } \\
\text { "Identitas" }\end{array}$ & $\begin{array}{c}\text { Jakarta, } 07-14 \\
\text { Agustus } 2020\end{array}$ & Lokal & $\begin{array}{l}\text { Rizki Rizal (23), } \\
\text { Mahasiswa } \\
\text { Putri Rizka (22), } \\
\text { Mahasiswi } \\
\text { Rizky Abdullah (23), } \\
\text { Mahasiswa }\end{array}$ \\
\hline $\begin{array}{l}\text { "Relijiusitas" } \\
\text { Kontemporer } \\
\text { Nusantara }\end{array}$ & $\begin{array}{l}27 \text { Oktober }-09 \\
\text { November } 2020\end{array}$ & Nasional & $\begin{array}{l}\text { Wahyu Nugroho } \\
\text { (53), Seniman }\end{array}$ \\
\hline $\begin{array}{l}\text { Pameran Drawing } \\
\text { AlkmaArt "Orek-Orek" }\end{array}$ & $\begin{array}{c}\text { Purwosari, } 11 \text { Mei } \\
2020\end{array}$ & Nasional & $\begin{array}{l}\text { Reza Ahmad Fauzi } \\
\text { (23), Mahasiswa }\end{array}$ \\
\hline $\begin{array}{l}\text { Pameran Swakarya } \\
\text { Kolektif }\end{array}$ & $\begin{array}{c}\text { Nganjuk, } 15 \text { Mei } \\
2020\end{array}$ & Nasional & $\begin{array}{l}\text { Achmad Yusril Ismal } \\
\text { (22), Mahasiswa }\end{array}$ \\
\hline $\begin{array}{l}\text { GI Arscademia "Dunia } \\
\text { Esok Hari" }\end{array}$ & $\begin{array}{l}\text { Bali, } 10 \text { Agustus - } \\
10 \text { September } 2020\end{array}$ & Nasional & $\begin{array}{l}\text { Danar Pintar Najati } \\
\text { (21), Mahasiswa }\end{array}$ \\
\hline
\end{tabular}

\section{TEMUAN DAN PEMBAHASAN}

\section{Tangibles (Bentuk fisik)}

Berdasarkan hasil wawancara dengan tujuh orang narasumber ditemukan bahwa empat orang pengguna jasa dalam pameran secara daring atau virtual sangat memengaruhi kualitas karya mereka, dua di antaranya mengatakan bahwa pemangku kepentingan tidak dapat menyesuaikan penataan karya yang dipamerkan (display), sehingga mengurangi kualitas karya seperti karya yang seharusnya 3D (tiga dimensi) menjadi 2D (dua dimensi) atau konsep display yang sedikit nyeleneh dan dirasa kurang menarik bagi pengguna jasa, sedangkan dua orang lainnya mengatakan bahwa konsep dari pemangku kepentingan mengharuskan mereka untuk mengubah bentuk dan ukuran karya karena untuk menyesuaikan ukuran ruang dan penggunaan aplikasi, sehingga sejalan dengan pernyataan Iordache (2010) yaitu karya seni mengalami beberapa perubahan saat berada di situasi yang baru.

Dari hal tersebut dapat kita lihat bahwa konsep dari pemangku kepentingan sangat memengaruhi kualitas karya para peserta pameran atau pengguna jasa dan temuan tersebut juga sesuai dengan penelitian Wu dkk. (2016), yang menyatakan bahwa bentuk fisik dari kualitas fisik merupakan yang paling berpengaruh terhadap kualitas mutu layanan yang dirasakan oleh pengguna jasa. 


\section{Reliability (Keandalan)}

Kualifikasi yang harus dimiliki seorang pengguna jasa dalam mengikuti sebuah pameran daring atau virtual adalah kemampuan dalam memahami konsep dari pameran serta mempersiapkannya sesuai dengan keinginan dari pemangku kepentingan sebagai penyelenggara pameran daring. Hal ini karena pameran daring atau virtual menggunakan beragam media dan format karya, baik berupa foto maupun berupa video, sehingga pengguna jasa perlu mempertimbangkan bagaimana karya mereka dapat menyesuaikan media tersebut. Oleh karena itu, sejalan dengan penelitian Schubert (2008), di mana pameran virtual lebih banyak melibatkan beragam media dalam satu sistem, sehingga pengguna jasa perlu memperhatikan hal tersebut sejak awal sebelum mengikuti pameran daring atau virtual.

Dari temuan tersebut, reliability (keandalan) seorang pengguna jasa juga memberikan kontribusi dalam meningkatkan kualitas pameran virtual dari kualifikasi yang dimilikinya. Beberapa temuan dari keseluruhan narasumber, yang terjadi dalam pameran virtual menghasilkan sedikit kendala yang tidak terlalu berpengaruh terhadap kepuasan pengguna jasa, karena telah teratasi dengan baik oleh pemangku kepentingan, seperti keinginan dari pengguna jasa sebagai partisipan yang ingin memosisikan karyanya dalam penataan karya yang dipamerkan (display), namun hal tersebut hanya bisa dilakukan oleh pemangku kepentingan, seperti yang dijelaskan oleh Biddle (2020), di mana seorang pemimpin yang merupakan bagian dari pemangku kepentingan harus memahami pentingnya tetap terhubung dan bersikap proaktif dalam mengubah pengaturan fisiknya.

\section{Responsiveness (Cepat Tanggap)}

Menurut keseluruhan narasumber sebagai pengguna jasa, pemangku kepentingan menggunakan sosial media sebagai sarana informasi. Enam dari tujuh mengatakan pemangku kepentingan sudah tepat memilih aplikasi WhatsApp, sedangkan satu narasumber mengatakan pameran yang diikuti menggunakan email sebagai jalur komunikasi dan informasi, namun secara keseluruhan pemangku kepentingan sudah memberikan informasi dengan baik dan cepat dalam menghubungi peserta pameran meskipun tidak pernah bertatap muka sebelum dan selama pameran berlangsung. Dari keterangan di atas, dapat disimpulkan bahwa meskipun pameran secara virtual/daring dan tidak melakukan tatap muka, pemangku kepentingan telah memberikan kepuasan terhadap pengguna jasa dalam hal responsiveness dengan memberikan respons secara cepat terkait informasi yang disampaikan, sejalan dengan temuan Bennett (2020), bahwa pertemuan virtual memiliki potensi untuk memperluas cara kita mengalami keintiman, koneksi, dan sentuhan virtual. 


\section{Empathy (Empati)}

Dalam pameran daring atau virtual, keseluruhan narasumber menjelaskan bahwa terdapat perbedaan dalam pameran daring dan pameran fisik (luring), sejalan dengan penelitian Bonis,. dkk (2013), mereka mengatakan pameran secara daring memberikan jangkauan yang luas, berbeda dengan pameran fisik yang hanya sebatas lingkup wilayah ruang dan dalam pameran virtual pengguna jasa dapat dengan leluasa untuk mengunjungi kembali untuk melihat karya mereka kapanpun. Kemudian, dari sudut pandang pemangku kepentingan sebagai penyelenggara dalam pameran virtual ataupun daring sudah sangat memahami karya dari para pengguna jasa dan merancang karya dengan sebaik mungkin, hal tersebut dibuktikan oleh enam dari tujuh narasumber yang merasa puas terhadap pemangku kepentingan yang telah memahami karya mereka, dan hanya satu orang yang merasa bahwa pemangku kepentingan belum memahami karyanya dikarenakan display yang kurang baik. Hal ini membuktikan bahwa pemangku kepentingan dalam pameran virtual/ daring memiliki kualitas mutu layanan yang baik dilihat dari sudut dimensi empati, sejalan dengan penelitian Wu, dkk. (2016), bahwa perilaku petugas terhadap pengguna jasa, termasuk dalam memahami karya mereka merupakan bagian penting dalam menemukan sebuah kualitas dari pameran virtual.

Pengalaman dalam mengikuti pameran secara virtual merupakan hal yang baru dan pertama dirasakan oleh para narasumber sebagai pengguna jasa. Berbagai respons yang berbeda dari setiap narasumber memberikan banyak kesan di setiap masing-masing pameran yang diikuti, serta masalah yang harus dihadapi bagi pameran daring atau virtual adalah pemangku kepentingan sebagai penyelenggara perlu memikirkan penggunaan fitur atau aplikasi dalam men-display pameran tersebut dikarenakan kualitas karya juga ditentukan oleh bagaimana pemangku kepentingan men-display karya dengan baik. Hal tersebut dibuktikan oleh lima dari tujuh narasumber mengatakan bahwa kualitas dalam men-display karya menjadi masalah yang harus dihadapi oleh pemangku kepentingan sehingga mereka perlu memperhatikan penataan dalam men-display karya dari pengguna jasa. Temuan tersebut sejalan dengan penelitian Edgar (2002), bahwa pentingnya setiap organisasi atau pemangku kepentingan untuk mengembangkan rencana pemasaran yang baik, salah satunya merancang tatanan display karya untuk menarik.

\section{Assurance (Jaminan)}

Dari berbagai pengalaman yang dirasakan oleh pengguna jasa sebagi partisipan, terdapat berbagai kekhawatiran dalam mengikuti pameran virtual yang akan datang. Empat narasumber menjelaskan bahwa kekhawatiran datang dari kesulitan dalam bertatap muka, kemudian satu narasumber mengatakan kualitas pada sistem kurasi yang dikhawatirkan tidak maksimal dalam memilih karya, 
namun keseluruhan narasumber memberikan tanggapan positif dan memaklumi apa yang terjadi pada masa pandemi Covid-19 ini yang mengharuskan untuk mengubah pameran menjadi virtual/daring, dan meskipun terdapat kekhawatiran, mereka akan tetap terus berkarya.

Temuan tersebut sejalan dengan penelitian dari Xiaodan (2020) yang mana pameran virtual menjadi salah satu respons dari pandemi Covid-19, dan walaupun memiliki keterbatasan dalam hubungan tatap muka, namun partisipan memberikan kontribusi yang besar untuk terus melakukan pameran dengan berbagai aspek dan tujuan masing-masing. Dari hal tersebut, menjelaskan bahwa meskipun pameran virtual memberikan assurance (jaminan) kepada pengguna jasa, hal tersebut bukan berasal dari kualitas layanan pemangku kepentingan, namun lebih kepada kesadaran pengguna jasa sebagai partisipan untuk terus berkarya.

Selain dari keharusan pengguna jasa untuk tetap berkarya dan melakukan pameran, situasi pandemi Covid-19 juga dimanfaatkan oleh narasumber karena mengeluarkan biaya yang tidak banyak, seperti tidak adanya pengiriman karya dan properti yang dibutuhkan karena segalanya menggunakan ruang media daring, seperti yang telah dijelaskan dalam penelitian Carollina (2020), bahwa pameran virtual memangkas biaya produksi dan biaya untuk mengirimkan karya, dan sejalan dengan Khoon (2008), bahwa pameran daring menghadirkan solusi praktis dan hemat biaya untuk keterbatasan pameran fisik, serta mereka tidak lagi dibatasi waktu, jarak, dan ruang sehingga dari hal tersebutlah menjadi jaminan bahwa pengguna jasa akan tetap melakukan pameran meskipun di dalam ruang virtual.

\section{KESIMPULAN}

Pembatasan sosial yang terjadi selama pandemi Covid-19 ini adalah realitas yang tidak bisa ditolak oleh para seniman dan seluruh umat manusia. Pameran daring sebagai upaya kreatif dan inovatif para perupa perlu diapresiasi dengan segala keterbatasan. Dalam upaya tersebut kerja sama dengan para pemangku kepentingan sangat penting untuk dilakukan karena pameran daring melibatkan banyak pihak yang tidak ditemui pada pameran luring.

Pameran daring atau virtual memberikan sentuhan dan pengalaman yang baru bagi para pengguna jasa sebagai partisipan dan tentunya bagi pemangku kepentingan sebagai penyelenggara. Meskipun dilakukan secara virtual atau daring, pameran tersebut masih memiliki kualitas yang baik dalam segi mutu layanan, namun dari lima dimensi tersebut dimensi bentuk fisik (bukti fisik), reliabilitiy (keandalan), responsiveness (cepat tanggap), dan empathy (empati) dalam pameran virtual memiliki kualitas yang baik dan secara positif memberikan dampak kepuasan terhadap pengguna jasa, sedangkan pada dimensi assurance (jaminan) dalam kualitas layanan pemangku kepentingan tidak memengaruhi kepuasan 
terhadap pengguna jasa, karena ditemukan bahwa kualitas assurance (jaminan) berasal dari kesadaran pengguna jasa dalam berkarya yang harus tetap mengikuti pameran walaupun dengan situasi yang berbeda.

Oleh karena itu, sebagai penyedia jasa, pemangku kepentingan perlu memperhatikan keempat dimensi yang sangat memengaruhi kepuasan dari pengguna jasa sebagai partisipan pameran daring, karena pameran daring menjadi hal baru bagi sebagian masyarakat, sehingga pemangku kepentingan harus meningkatkan kualitas mutu layanan pameran daring mereka agar dapat menarik bagi target pengguna jasa untuk mengikuti pameran virtual tersebut. Dan untuk penelitian selanjutnya, diharapkan mampu menemukan bagaimana kualitas mutu layanan dari sudut pandang pengunjung yang menikmati sebuah pameran daring atau virtual.

\section{KEPUSTAKAAN}

A. Parasuraman, Valarie A. Zeithaml, and Leonard L. Berry. (1988). "SERVQUAL: A Multiple-Item Scale for Measuring Consumer Perceptions of Service Quality". Journal of Retailing. Vol 64 (1) pp 12-37.

Anderson, J. E. (1979). Public Policy Making. New York: Holt, Rinehart, and Winston.

Anggiansyah. (2018). Analisis Persepsi dan Harapan Pelanggan Terhadap Kualitas Layanan Galeri Sangkring Art Space. Jurnal Tata Kelola Seni, Vol.4, No.1.

Bennett, Naomi P. (2020). Telematic Connections: Sensing, Feeling, Being in Space Together. International Journal of Performance Arts and Digital Media, Vol. 16, No. 3, 245-268.

Biddle, Christopher J. (2020). Epidemics and Pandemics as High Consequence Events: Expanding Leadership Challenges and Responsibilities in Business Continuity During the COVID-19 Pandemic and Beyond. Journal of Business Continuity \& Emergency Planning, Volume 14 Number 1.

Bonis, Bill, Et all. (2013). "Adaptive Virtual Exhibitions". Journal of Library \& Information Technology, Vol. 33, No. 3.

Brinkmann, S. dan Kvale, S. (2015). Interviews Learning the Craft of Qualitative Research Interviewing, Third Edition. United States of America: Sage Publications.

Budiyanto, Hery dkk. (2020). Virtual Expo Menggunakan Panggung sebagai Solusi Pameran Daring di Masa Pandemi COVID-19. Jurnal Pengabdian.

Carollina, Donna. (2020). Graffiti Virtual Exhibition "Pandemic Youth". International Journal of Creative and Art Studies, Volume 7 Number 2.

Edgar, Janice. (2002). "Virtual Exhibitions: A New Product of the IT Era". Journal of Convention \& Exhibition Management, Volume 4, Issue 2.

Feng, Xiaodan. (2020). "Curating and Exhibiting for the Pandemic: Participatory Virtual Art Practices During the COVID-19 Outbreak in China". Journal of social media and Society, Volume 6, Issue 3, pp 1-6. 
Foo, Schubert. (2008). "Daring Virtual Exhibitions: Concepts and Design Considerations". Journal of Library and Information Technology, Vol. 28, No. 4 pp. 22-34.

Iordache, Rares. (2010). From Transgression to Virtual Space or the End of Art. Journal of Styles of Communication, No. 2.

Khairunnisa, Indira dkk. (2021). Inovasi Virtual Exhibition Masa Depan. Jurnal ALTASIA, Volume 3, Nomor 1.

Khoon, Leong Che and Chennupati K.Ramaiah. (2008). "An Overview of Daring Exhibitions". Journal of Library and Information Technology, Vol. 28, No. 4, pp. 7-21.

Lu, Lily. (2013). 30 Virtual Worlds as Art Media and Exhibition Arenas: Students' Responses and Challenges in Contemporary Art Education. Journal of Issues and Research. 54(3), 232-245.

Maulina, Rini dan Setiawan Sabana dan Nuning Damayanti. (2019). "E-Gallery untuk Pameran Daring Studi Kasus: Karya Seni Rupa Indung”. [Prosiding]. Seminar Nasional Sandyakala.

Rahmawati, Hanif Zuhana. (2015). Potensi Manajemen Seni dalam Pengembangan Karir Perupa. Jurnal Desain dan Seni, Volume 2, Edisi 3.

Ramaiah, Chennupati K. (2014). "Trends In Daring Exhibitions". Journal of Library \& Information Technology, Vol. 34, No. 2, pp. 83-86.

Masyarakat Universitas Merdeka Malang Vol.5 (3).

Salim, Polniwati. (2018). Persepsi Kualitas Ruang Pamer Museum Seni: Sebuah Studi Observasi. Jurnal Desain \& Seni, Volume 5 Edisi 2.

Tjiptono, Fandy dan Gregorius Chandra. (2016). Service Quality dan Satisfaction: Edisi 4. Yogyakarta: ANDI.

Wu, Hung-Che, Et All. (2016). "A Study of Exhibition Service Quality, Perceived Value, Emotion, Satisfaction, And Behavioral Intentions". Journal of Event Management, Vol. 20, Pp. 565-591. 